\title{
An Investigation of the Bacterial Influence of Acidithiobacillus Thiooxidans on Concrete Composites
}

\author{
Vlasta Ondrejka Harbulakova ${ }^{1,{ }^{*}}$, Adriana Estokova ${ }^{2}$, and Alena Luptakova ${ }^{3}$ \\ ${ }^{1}$ Technical University of Kosice, Faculty of Civil Engineering, Department of Environmental \\ Engineering, Vysokoskolska 4, 04200 Kosice, Slovak Republic \\ ${ }^{2}$ Technical University of Kosice, Faculty of Civil Engineering, Department of Material Engineering, \\ Vysokoskolska 4, 04200 Kosice, Slovak Republic \\ ${ }^{3}$ Slovak Academy of Science, Institute of Geotechnics, Watsonova 45, 04001 Kosice, Slovak \\ Republic
}

\begin{abstract}
Vegetation and microorganisms present the biological factors that deteriorate concrete. These problems are very visible in places like sewage, underground and hydraulic structures, chemical plants, industrial structures, liquid-containing structures, agricultural structures or marine environments. The most significant biodeteriogens are the sulphur-oxidising bacteria Acidithiobacillus thiooxidans (A. thiooxidans) and the sulphatereducing bacteria (Desulfovibrio spp.) that are responsible for the so-called sulphuretum consortium. Microorganisms that produce sulphuric acid accelerate the deterioration of concrete sewer pipes in a process termed Microbially Induced Concrete Corrosion (MIC). The paper considers the assessment of the release of calcium and silicon from concrete composites with and without coal fly ash by sulphur-oxidizing bacteria. The concrete mixture contained coal fly ash as $5 \mathrm{wt}$. \% and wt. $10 \%$ cement replacement. Prepared composites were exposed to an aggressive microbial environment under laboratory conditions for 3 months. The $\mathrm{pH}$ values were measured and studied during this time period. A different resistance against MIC was observed for the concrete composites of different compositions. The highest amount of calcium leached-out from the concrete was in the case of the composites where $10 \%$ cement was replaced by fly ash.
\end{abstract}

\section{Introduction}

All concrete structures are exposed to the environment which is why consideration of the environmental conditions under which the concrete is to function during its operation has to be taken into consideration.

The mechanisms of concrete deterioration may have a chemical, physical, or mechanical character [1]. Hydrochloric, nitric, sulfuric, chloric, chromic and other acids are very dangerous for concrete. An acidic attack is very intensive because all the hydration products

\footnotetext{
* Corresponding author: vlasta.harbulakova@gmail.com
} 
of cement can be finally decomposed [2]. Sulfuric acid appears in different aspects: from industrial wastewater, within a sewage system, e.g. water, wastewater, storm water [3-5] which can be contaminated with organic and inorganic compounds [6,7] and also from groundwater. An acidic attack may also occur as a consequence of bacterial activity which is able to produce acidic products like hydrogen sulphide or sulfuric acid. Five species of Acidithiobacillus bacteria (A. thioparus, A. novellus, A. intermedius, A. neapolitanus, A. thiooxidans) are primarily responsible for sulfuric acid production during the biological corrosion process [8]. Water must always be present in the deterioration processes because it acts as a solvent of an aggressive medium, then, in some cases as a constituent of the formatted reaction product [2].

The usage of fly ash in concrete has had a successful record over the past several decades. It has been well researched and documented in actual structures and the benefits to the mechanical and durability properties of concrete have been performed [9]. There was some basis for restricting its use in the 70 s, however nowadays these restrictions are no longer valid [10]. Higher levels (30\% to 50\%) have been used in foundations and dams for example to control the temperature rise. Very high levels (40\% to 60\%) ensure production of a concrete with good mechanical properties and durability [11]. In general, fly ash appears to improve the resistance of concrete and mortar to sulfuric acid degradation. The exact reason for the improved resistance has not yet been defined. As the concentration of acid increases, the positive effect of fly ash inclusion is less apparent [12]. Fly ash belongs to type II addition (to the group of latent hydraulic material) according to the European Standard EN 206:2013: Concrete [13].

Khalil et al 2015 [14] studied concrete samples with fly ash (a replacement of 25\%) and various additions of silica fume ( 5 of $10 \%$ respectively). They confirmed that fly ash is more effective in changing the carbonation rate than that of the silica fume content. The improved resistance of concrete composites with fly ash replacement when exposed to $2 \%$ sulphuric acid were confirmed in the paper by [15]. In the case of samples containing up to $70 \%$ fly ash replacement, Aydin 2007 [16] presented less than 5\% reduction of mass loss in comparison to the reference samples after the effect of $5 \%$ sulfuric acid solution during 2 months.

In this paper, the influence of $A$. thiooxidans on concrete was studied through the leaching of calcium and silicon ions and the analysis of changes in $\mathrm{pH}$.

\section{Material and Methods}

The prepared concrete composites (cylinders drilled from concrete blocks) were placed in bacterial liquid medium at a temperature of $30^{\circ} \mathrm{C}$ over a period of 80 days. The biotic environment was simulated by $A$. thiooxidans ( $\mathrm{pH}$ growth range $0.5-3$; temperature $26^{\circ} \mathrm{C}$ ), which was isolated from an acid mine drainage from the Pech shaft (locality of Smolnik, Eastern Slovakia). A selective nutrient medium, according to Waksman and Joffe, was used for the isolation and cultivation of the active bacterial culture and for the microbial induced corrosion experiments. The concrete composites were half submerged in the liquid medium where $150 \mathrm{ml}$ of selective nutrient medium with $10 \%$ inoculum of active bacterial culture was placed (samples 0FA, 5FA and 10FA).

Abiotic controls (samples 0 Control, 5 Control, 10 Control) were realized under the same laboratory conditions, but without the bacteria.

Table 1 shows the composition of the concrete's mixes used in the experiments. Sample 0FA represented the reference sample without any addition of fly ash, while samples 5FA and 10FA represented the samples with a different proportion ( 5 or $10 \%$ respectively) of the fly ash. 
A chemical composition of the concrete samples' leachates (calcium and silicon) and the $\mathrm{pH}$ of the liquid medium were investigated periodically during the studied period. The $\mathrm{pH}$ values of the liquid medium were measured at the beginning, as well as in 7-day intervals.

Table 1. Characteristics of the concrete composites.

\begin{tabular}{|c|r|c|}
\hline $\begin{array}{c}\text { Designation of the } \\
\text { concrete composites }\end{array}$ & $\begin{array}{c}\text { Character of the composites } \\
\text { according to the presence of bacteria }\end{array}$ & $\begin{array}{c}\text { \% of fly ash in } \\
\text { the concrete } \\
\text { composite }\end{array}$ \\
\hline 0FA & A. thiooxidans & \multirow{2}{*}{0} \\
\hline 0 Control & Abiotic control to $0 \%$ FA composite & \multirow{2}{*}{5} \\
\hline 5FA & A. thiooxidans & \multirow{2}{*}{10} \\
\hline 5 Control & Abiotic control to 5\% FA composite & \\
\hline $10 \mathrm{FA}$ & A. thiooxidans & \\
\hline 10 Control & Abiotic control to 10\% FA composite & \\
\hline
\end{tabular}

The content of calcium leached out from the concrete composites into the liquid media was measured by atomic absorption spectrometry (SPEKTRAA 240FS/240Z, Varian). The content of silicon was determined by absorption spectrometry when after the chemical reaction a specifically coloured product was created. The absorbance is measured in $430 \mathrm{~nm}$ wavelength [17].

A MetLab PHM210 $\mathrm{pH}$ meter was used for the estimation of $\mathrm{pH}$ value changes in the leachates.

\section{Results and Discussion}

Fig. 1-3 shows the $\mathrm{pH}$ value changes in the liquid phases with the influence of $A$. thiooxidans bacteria according to the type of concrete composites.

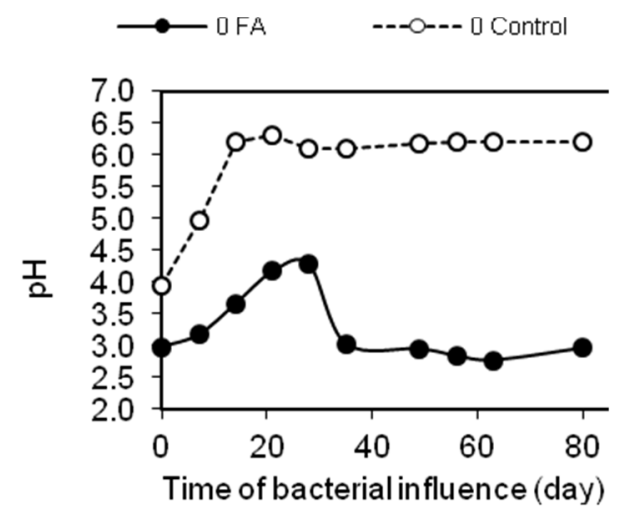

Fig. 1. $\mathrm{pH}$ changes in liquid media of composites without fly ash. 


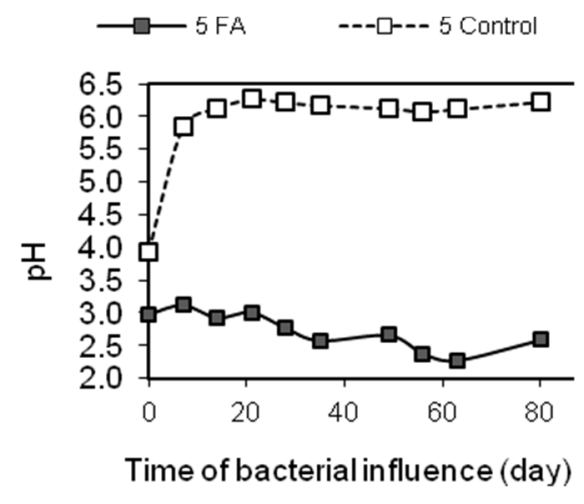

Fig. 2. $\mathrm{pH}$ changes in liquid media of composites with the addition of 5\% fly ash.

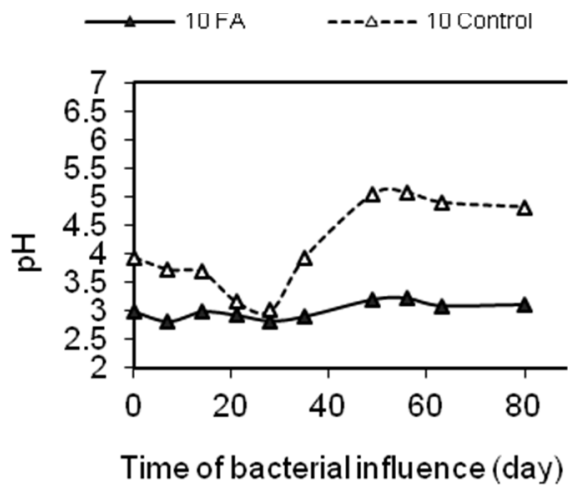

Fig. 3. $\mathrm{pH}$ changes in liquid media of composites with the addition of $10 \%$ fly ash.

The investigation of composites with a bacterial influence showed small changes of $\mathrm{pH}$ values in comparison with the starting value of the $\mathrm{pH}$ (except composite 0FA). In the liquid phase of composite 5FA the values were from 2.1 to 3.1 (Figure 2) while in 10FA it was from 2.8 to 3.5 (Figure 3 ). It refers to the production of sulphuric acid by A. thiooxidans bacteria that acidified the liquid phases, and the alkali character of the concrete could not be expressed. The influence of biogenic sulphuric acid was observed for composites 5FA and 10FA during the whole period of the experiment. When considering the composite 0FA this influence appears after 28 days into the experiment (Figure 1).

The increase of $\mathrm{pH}$ values for composites stands for abiotic control ( 0 Control and 5 Control) is presented in Figure 1 and 2. The values of $\mathrm{pH}$ reached the alkali zone after 20 days into the experiments and did not changed significantly until the end of experiment. It can be explained by the alkaline character of the concrete ( $\mathrm{pH}$ values from $11-13$ ) and its immersion in a liquid of an acidic attribute [18]. In the case of 10 Control an initial decrease in $\mathrm{pH}$ was noticed before it starts to increase with the same alkalization reasons (Figure 3).

The highest amount of calcium (Figure 4) is leached out from the composite with $10 \%$ fly ash replacement exposed to bacterial effect (10 FA). On the other hand, in the case of composites with only $5 \%$ fly ash as well as absolutely without fly ash replacement, the opposite trend is observed. 


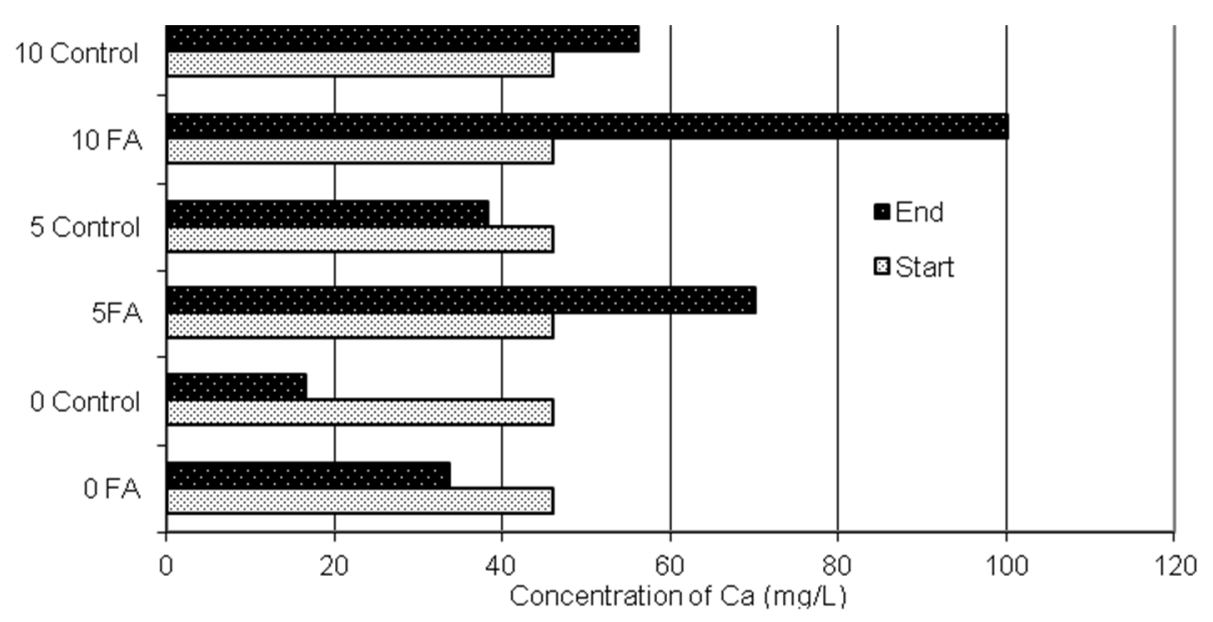

Fig. 4. Changes of $\mathrm{Ca}$ concentration in the liquid media after bacterial influence.

When for composite 10 FA the concentration of calcium increase in comparison with the initial conditions (start of experiment), composites 5 FA and 0 FA show a decreasing trend in calcium leaching (lower calcium amount in leachates at the end of experiment).

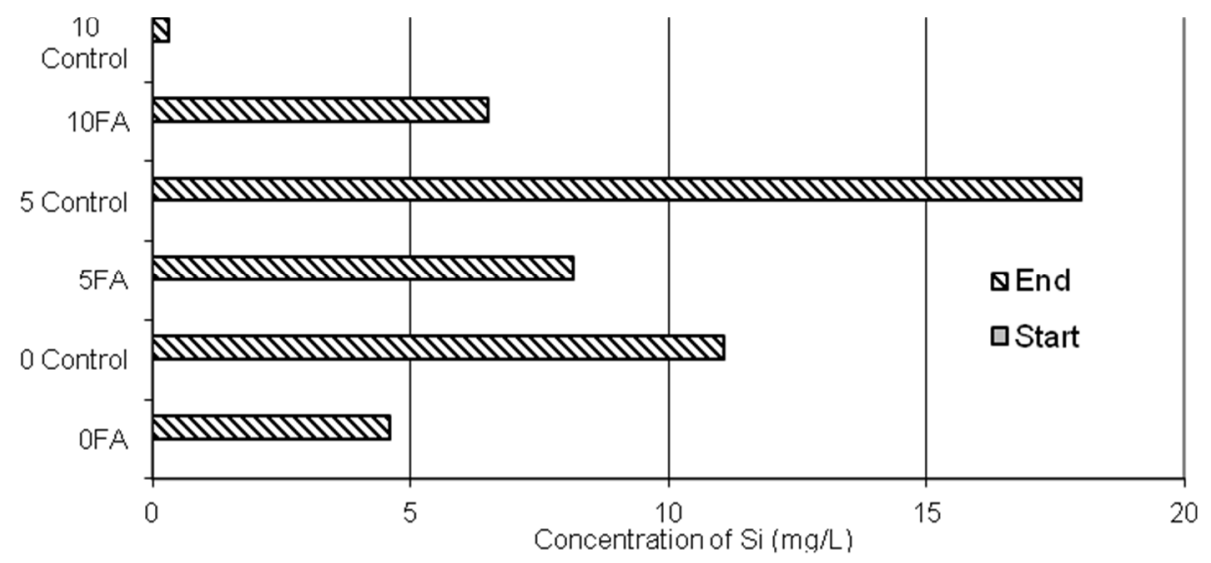

Fig. 5. Si concentration in the liquid media after bacterial influence.

As is shown in Fig. 5, the biologically affected samples with 0 and 5\% fly ash proved lower silicon leaching than the corresponding control samples without bacteria. The dissolved silicon amounts from these control samples are almost twice higher than from those exposed to bacteria. A totally different trend was observed in the case of the sample with 10 $\%$ fly ash. The silicon leaching from the samples with 0 and $5 \%$ fly ash is in contrast with the calcium leaching as seen in Fig. 5.

Based on the findings, it can be concluded that the biologically affected samples, both with and without fly ash, proved a higher calcium release from the cement matrix than the 
control samples. However, we cannot definitely conclude a more significant effect of bacteria regarding silicon leaching.

\section{Conclusion}

In the paper an investigation of the influence of the aerobic bacteria $A$. thiooxidans on biodeterioration on concrete composites is presented. The studied composites were prepared in three different mixtures (standard recipe, mixture containing coal fly ash as $5 \mathrm{wt} . \%$ and 10 $\%$ cement replacement) showed different resistance against bacterially produced sulphuric acid during the 80-day experiment. Acidic liquid increased the leaching of calcium from the concrete matrix in the case of all of the studied composites. The highest calcium content (considering the influence of bacteria) was leached from composite 10FA and the highest content of silicon was leached from the composite 5FA.

The research was supported by Grant No. 2/0145/15 of the Slovak Grant Agency for Science.

\section{References}

1. A. J. Biyd, J. Skalny, WIT Transaction on State of the Art in Science and Engineering, 84 (WIT Press, 2007)

2. V. Zivica, A. Bajza, Constr. Build. Mater., 15 (2001)

3. S. Todeschini, S. Papiri, C. Ciaponi, Water. Resour. Manag., DOI: 116.10.1007/s11269-018-1964-y (2018)

4. K. Pochwat, D. Słyś, S. Kordana, J. Hydrol., 549 (2017)

5. P. Pelikan, M. Slezingr, J. Markova et al., Pol. J. Environ. Stud. 2 (2018)

6. M. Kida, S. Ziembowicz, P. Koszelnik, Sep. Purif. Technol., 192 (2018)

7. L. Bartoszek, P. Koszelnik, R. Gruca-Rokosz, M. Kida, Rocz. Ochr. Śr. 17 (2015)

8. B. R. L. Islander, J. S. Devinny, A. Member, F. Mansfeld, A. Postyn, H. Shih, J. Environ. Eng. 117 (1992)

9. H. K. Obla, InFocus, Spring 2008

10. ACI 318-05 Building Code, ACI Manual of concrete practice, America Concrete Institute (2002)

11. M. L. Marceau, J. Gajda, M. G. Van Geem, PCA R\&D Serial No. 2604, (Portland Cement Association, 2002)

12. M. Wayne House, A Dissertation Thesis (Purdue University, Indiana, 2013)

13. European Standard EN 206:2013 Concrete- Specification, Performance, Production and Conformity (2013)

14. E. A. B. Khalil, M. Anwar, Water Sci. 29 (2015)

15. K. Tori, M. Kawamura, Cem. Concr. Res., 24 (1994)

16. S. Aydin, S. Yazici, H. Yigiter, B. Baradan, Build. Environ. 42 (2007)

17. M. Horakova, P. Lischke, A. Grunwald, (SNTL Prague: ALFA Bratislava, 1986) /in Slovak/

18. F. M. Lea, (Edward Arnold Ltd., Third Edition, London, 1970) 